
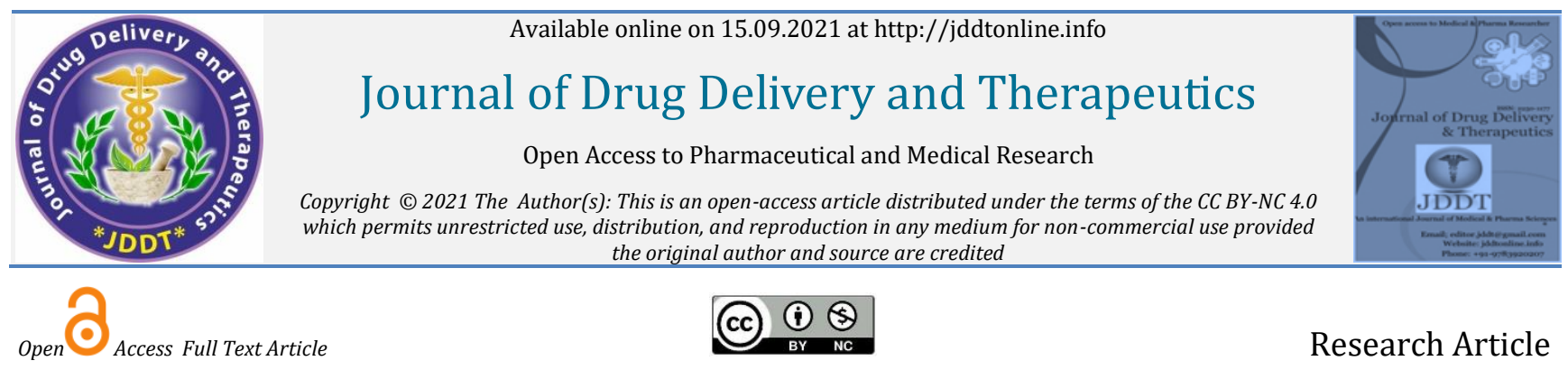
the original author and source are credited

\title{
Date Powder as Alternative Carbone Source in Optimizing the Cultivation of (Bacillus megaterium) in Submerged State Fermentation
}

\author{
${ }^{1 * H a y y a n ~ I ~ A l-T a w e i l @, ~} 1$ Yahya Aldawood, ${ }^{2}$ Heba Alhamal \\ ${ }^{1}$ Mohammed Al-Mana College for Medical Sciences, Abdulrazaq Bin Hammam Street, As Safa, Dammam 34222, Saudi Arabia \\ ${ }^{2}$ Saad College of Nursing and Allied Health Sciences- Al-Khobar, Eastern Province, Kingdom of Saudi Arabia
}

\section{Article Info:}

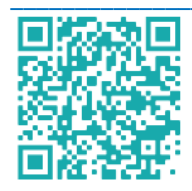

Article History:

Received 15 July 2021

Reviewed 19 August 2021

Accepted 25 August 2021

Published 15 Sep 2021

\section{Cite this article as:}

Al-Taweil HI, Aldawood Y, Alhamal H, Date Powder as Alternative Carbone Source in Optimizing the Cultivation of (Bacillus megaterium) in Submerged State Fermentation, Journal of Drug Delivery and Therapeutics. 2021; 11(5):47-51

DOI: http://dx.doi.org/10.22270/jddt.v11i5.4982

\section{*Address for Correspondence:}

Hayyan I Al-Taweil, Mohammed Al-Mana College for Medical Sciences, Abdulrazaq Bin Hammam Street, As Safa, Dammam 34222, Saudi Arabia

ORCID ID: https://orcid.org/0000-0001-7015-7749

\section{Abstract}

Problems statement: A study had shown a strain of Bacillus megaterium was isolated from the soil. Questions were whether date powder could be used as alternatives of carbon sources for Bacillus megaterium submerged state cultivation?

Approach: To evaluate the effects of the using date powder; The fermentation was carried out in shake flasks using a complex medium consisting of $(\mathrm{g} / \mathrm{L})$ ammonium tartrate, 2.0; magnesium sulphateheptahydrate, 4.0; dipotassium phosphate, 14.0; calcium chloride, 0.2 , $\mathrm{NaHPO} 4,4.0$, yeast extract, 3.0 , trace elements, $2.0 \mathrm{ml}$ and glucose $6.0(4.0$, yeast extract, 3.0 , trace elements, $2.0 \mathrm{ml}$ and glucose 6.0 ) were replaced by dates powder at three rates; 5,10 and $15 \mathrm{~g} / \mathrm{L}$

Results show that the rate of production of biomass during submerged fermentation by Bacillus megaterium at $30 \pm 1^{\circ} \mathrm{C}$ for 24 hours of incubation using date powder was maximizes between 18 and $24 \mathrm{hr}$ of fermentation. The experimental runs and results for the BoxBehnken design. The 15 runs in a single block were used to study the effects using date powder in different rates on one response. Biomass concentration ranged from $6.5 \mathrm{cfu} / \mathrm{l}$ to 12.9cfu /.comparing with $14.8 \mathrm{cfu} / \mathrm{g}$ for the commercial growth media. The ANOVA tables give the statistical significance of the effects for biomass. These effects were dates powder rates, the optimized growth medium with $\mathrm{pH} 7$, inoculums' size $10^{6}$, temp $24^{\circ} \mathrm{C}$ and moisture dates powder $15 \mathrm{~g} / \mathrm{L}$. The biomass concentrations obtained under the optimal conditions $12.9 \mathrm{cfu} / \mathrm{l}$

Key words: Date Powders, Fermentation, Bacillus megaterium, biomass, Submerged State

\section{INTRODUCTION}

Safe option was concerned by utilizing the characteristic materials in various scientific aspects, for organism's isolation, diverse kind of artificial development media to segregate microorganisms (Famurewa 0 and David OM.2008) ${ }^{1}$. Numerous studies had been accounted for to use cost effective nutrients. Annan-Prahetal 2010 utilized cowpea as elective culture media for microscopic organisms, cowpea builds the time span of usability of microorganisms. other investigation ${ }^{2}$, additionally reports that utilizing vegetables as an alternative source, for example, (potato, Groundnut, cereals, ect... ) for planning culture media for the development of fungi, yeasts and bacteria (Arulanantham R; et al. 2014) ${ }^{3}$.

Farther more Water soaked and date syrup can be used to inexpensively produce biomassin batch fermentations using B.megateriumas phosphorus solubilizing soil bacteria (AlTaweil et al 2015) ${ }^{4}$ in addition to many other sources of alternatives that used in microbial cultivation techniques and growth medias such as; legume seeds as alternativeculture media for fungi and bacteria., Used sweet potato agaras a medium to culture yeasts., waterextract ISSN: 2250-1177 (juice) from the root of Beta vulgaris (beetroot) understerile conditions, (Ojokoh AO and Ekundayo FO.2005)5,(Al-Azzauy AA and Hassan AM. 2011)6,( Zahraa Abd AlrazaqAbdalameer Alkhfaji, 2018,)7.

Bacillus megaterium is one of the most important biological control agents in the field of plant pathogens, since it can be used as bio- control agent and as suppler of some chemicals like magnesium, and detoxifying agent In addition to the Industrial applications of enzymes excreted by $B$. Megaterium (Al-Taweil et al,. 2015) ${ }^{4}$. Microorganisms are omnipresent and very diverse. Suitable culture media is one of the necessary to study them. Different microorganisms grow in different environments and have variety of growth requirements; like nutrients, $\mathrm{pH}$, osmotic conditions and temperature. The current limitations of cultivation of microbes in lab need to be addressed by formulation of newer media (Bhattacharya S, et al 2002) ${ }^{8}$.

Using submerged fermentation the optimal medium for producing the biomass was a mineral medium formulated with $8 \%$ of date syrup as the carbon source and $0.5 \mathrm{~g} / \mathrm{L}$ $(\mathrm{NH} 4)_{2} \mathrm{SO}_{4}$ as the nitrogen source. At optimal fermentation time of $48 \mathrm{hrs}$, at $30^{\circ} \mathrm{C}$ (Al-Taweil et al,. 2015) ${ }^{4}$. Growth of 
bacteria and pigment production efficiency was analyzed using nine formulations. The results showed that drumstick formulations having seed and peel extract, formulations B and D supported growth of E.coli, Serratia sp., and Pseudomonas sp.(Jadhav et.al 2018) ${ }^{9}$.

Potentials of cellulosic wastes in media formulation were investigated by Nwodo-Chinedu et al. (2009). Two agar media, were modified by substituting their carbon sources with cellulose, sawdust and sugarcane pulps. The modified Sabouraud's agar containing sawdust (Wood-Pep agar) and sugarcane pulps (Cane-Pepagar) yielded $84.4-100 \%$ of the maximum growth on Sabouraud's agar. Cellulose containing media gave a lower level of growth $(60.0$ to $66.7 \%)$ of that obtained for the unmodified media (Giovanni M 2008) ${ }^{10}$.

It was reported that in submerged fermentation, the enzyme production was initiated in the media containing 0.2 or $1.0 \%$ soluble starch, for Bacillus spp. While the maximum quantity of amylase was obtained at $35^{\circ} \mathrm{C}$. (Lonsane and Ramesh, 1990).it was found also in other studies, different organisms have different $\mathrm{pH}$ optima and decrease or increase in $\mathrm{pH}$ on either side of the optimum value results in poor microbial growth (Lonsane, B.K. \& Ramesh, M.V. 1990)11.

The present study is aimed at replacing carbon sources in artificial culture media by date powder to find an alternative media characterized by cheap cost and simple preparation could be used instead of the routinely commercial Carbone sources used in the microbiology laboratories.

\section{MATERIALS AND METHODS}

\section{Isolation of Producer Microorganism}

Indigenous Beneficial Microorganisms species was isolated from soil samples by using a selective medium (NA).Samples were dusted over the plates and the plates were incubated at $30 \pm 1^{\circ} \mathrm{C}$ for four days. The microbial colonies were developed which were picked up and purified by streaking and incubated at $30 \pm 1^{\circ} \mathrm{C}$ for $3 \mathrm{~d}$. Bacillus megaterium was isolated from soil in fermentation lab.

Date powder were bought from AL AMEEN DATES FACTORY (DATES POWDER- SUGAR SUBSTITUTE) Al HssaKSA www.alameendates.com

\section{Fermentation Parameters:}

The fermentation control media was carried out in shake flasks using a complex medium consisting of (g/L) ammonium tartrate, 2.0; magnesium msulphate heptahydrate, 4.0; dipotassium phosphate, 14.0; calcium chloride, 0.2, NaHPO4, 4.0, yeast extract,3.0 , trace elemts, $2.0 \mathrm{ml}$ and glucose 6.0 The flasks containing $200 \mathrm{~mL}$ fermentation medium were inoculated by $6 \mathrm{~d}$ old vegetative inoculum. (Difco Laboratories. USA. 1969.) ${ }^{12}$.

- Initial pH; 7

- Inoculums $10^{6} \mathrm{CFU} / \mathrm{ml}$

- Temperature; $24^{\circ} \mathrm{C}$

- In the test dates powder were used as alternative of carbon source:(g/L) ammonium tartrate, 2.0; magnesium sulphateheptahydrate, 4.0; dipotassium phosphate, 14.0; calcium chloride, 0.2, NaHPO4, and Dates Powder 5,10, and 15 g/ 1L

\section{Observations and determinations}

\section{- Bacterial Count Determination}

Bacterial count was determined by Optical density (OD) measurement of bacterial cultures using spectrophotometers, use $600 \mathrm{~nm}$ as ODs.(Jadhav et.al 2018)9 .

\section{- Specific Growth Rate}

To determine the specific growth rate $(\mathrm{m})$, natural log of biomass $(\ln \mathrm{X})$ was plotted against time $(\mathrm{t})$. The slope of the line at any moment gives the specific growth rate at that moment.

\section{Statistical Analyses}

Experiments were performed in triplicate and the results were statistically analyzed using computer software Response surface methodology (RSM) using a Box-Behnken design was applied to batch cultures, for identifying the effects of process variables :( table1).

- Initial ph; 7

- Inoculums $10^{6}$

- Temperature; $24^{\circ} \mathrm{C}$

- Dates Powder 5,10, and 15 g/ 1L

\section{RESULT AND DISCUSSION}

The rate of growth and growth rate is quite important in understanding their fermentation pattern. Table (1) shows the rate of production of bacterial growth during liquid media fermentation by Bacillus megaterium at $30 \pm 1^{\circ} \mathrm{C}$ for 24 hours of incubation. Maximum growth rate was observed between 18 and $24 \mathrm{hr}$ of fermentation. The experimental runs and results for the Box- Behnken design are shown in Table 1.The 15 runs in a single block were used to study the effects of three levels of date's powder. Biomass concentration ranged from $6.5 \mathrm{~g} / \mathrm{l}$ to $12.9 \mathrm{~g} /$. The ANOVA tables (Tables 2, 3) give the statistical significance of the effects for biomass. With regard to bacterial count, tow effects had $P$-values of less than 0.05 (Table 3), indicating that they were significantly different from zero at the $95 \%$ confidence level. These effects were the initial inoculums' size, and initial moisture content \%. Considering the $F$-ratio statistic (Table 2), it was concluded that a change in inoculums' size caused the major variation in biomass concentration. The effect of fermentation $\mathrm{pH}$ and temperature weren't statistically significant as biomass was harvested at the stationary growth phase.

The $R 2$ statistic (Table 3 ) indicated that the model as fitted explained $66.32 \%$ of the variability in biomass concentration. The adjusted $R 2$ statistic, which is more suitable for comparing models with different numbers of independent variables, was $60.93 \%$. The standard error showed the standard deviation of the residuals to be 0.99 The Durbin-Watson (DW) statistic tested the residuals to determine if there was any significant correlation based on the order in which they occurred in the data file. There was probably no significant autocorrelation in the residuals.

\section{Bacterial Cultivation}

From the analysis of the data by the least squares method, the following second-order model was fitted:

Biomass (cfu) $=+9.85+0.067 * \mathrm{~A}+1.39 * \mathrm{~B}-0.15 * \mathrm{C}+$ $0.22 * \mathrm{D}$ 
In order to optimize the cultivation of bio control agent in commercial form and in large quantities, The optimum parameters to the control fermentation growth medium with $\mathrm{pH} 7$, inoculums' size $10^{10}$, temp $24^{\circ} \mathrm{C}$ and $15 \mathrm{~g} / \mathrm{L}$ date powder. The biomass concentrations obtained under the optimal conditions $12.9 \mathrm{cfu}$.

Zahraa Abd Alrazaq et al 2018, found that the enzyme production was optimized at about $6 \mathrm{~h}$ in the media containing 0.2 or $1.0 \%$ soluble starch on the production of amylase by Bacillus spp., it was also observed for the production of "- amylase from Banana stalk using B. subtilis ${ }^{7}$. The results showed that BCPL1 broth medium was significantly better than BCPL2 broth to most tested BCPL3 broth medium. All tested yeasts grow least in solid alternative media BCPL1 and BCPL2 agar were more effective on G- BCPL3 bacteria and yeast than G+ bacteria while agar was effective for most tested organisms(Zahraa Abd- Alrazaq et al 2018) ${ }^{7}$.

Other study in using date syrup based medium to isolate Bacillus megaterium yielded a biomass of 6.1 and $4.6 \mathrm{~g} / \mathrm{l}$ for water soaked and date syrup respectively. Date products can be attained on media that used various other carbon sources (Al-Taweil et al 2015)4.

The results of this study indicate important effects of simple and complex carbon sources on growth and accumulation of B. megaterium.

The Model F-value of 12.31 implies the model is significant. Data analysis indicated that Values of "Prob > F" less than 0.0500 and the model terms were significant. In this case the alternatives effects were significant model terms. Values greater than 0.1000 indicated the model terms are not significant. If there are many insignificant model terms (not counting those required to support hierarchy), model reduction may improve your model.

According to the variance for Bacillus megaterium cultivation in submerged fermentation (R-Squared $=0.6632$ Adj R-Squared=0.6093 Std. Dev = 0.99).

Table1: Bacillus factor values and the responses of cultivation conditions as; $\mathrm{pH}$, inoculum size $1^{6}{ }^{6}$, temp $24{ }^{\circ} \mathrm{C}$ and different rate of date's powder.

\begin{tabular}{|c|c|c|c|c|c|}
\hline \multicolumn{2}{|c|}{ Initial PH } & \multicolumn{2}{c|}{ Inoculums' size } & Date Powder & Biomass \\
\hline $\mathbf{1}$ & 7 & 10 & 24 & 5 & 6.5 \\
$\mathbf{2}$ & 7 & 10 & 24 & 10 & 8.2 \\
$\mathbf{3}$ & 7 & 10 & 24 & 10 & 8.9 \\
$\mathbf{4}$ & 7 & 10 & 24 & 15 & 11.5 \\
$\mathbf{5}$ & 7 & 10 & 24 & 15 & 12,2 \\
$\mathbf{6}$ & 7 & 10 & 24 & 5 & 9.00 \\
$\mathbf{7}$ & 7 & 10 & 24 & 10 & 9.1 \\
$\mathbf{8}$ & 7 & 10 & 24 & 10 & 8.1 \\
$\mathbf{9}$ & 7 & 10 & 24 & 5 & 9.6 \\
$\mathbf{1 0}$ & 7 & 10 & 24 & 10 & 12.9 \\
$\mathbf{1 1}$ & 7 & 10 & 24 & 15 & 11.9 \\
$\mathbf{1 2}$ & 7 & 10 & 24 & 15 & 9.9 \\
$\mathbf{1 3}$ & 7 & 10 & 24 & 5 & 12.8 \\
$\mathbf{1 4}$ & 7 & 10 & 24 & 15 & 7.5 \\
$\mathbf{1 5}$ & 7 & 10 & 24 & 5 & \\
\hline
\end{tabular}

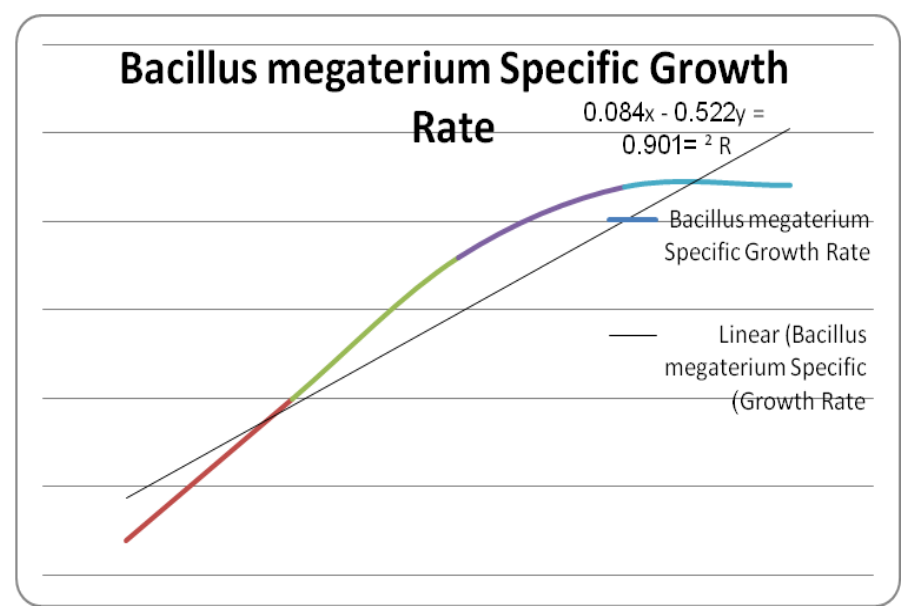

Figure 1: Specific growth rate of Bacillus megaterium 
Table 2 Analysis of variance for Bacillus megaterium cultivationin submerged fermentation(R-Squared=0.6632, Adj RSquared=0.6093 Std. Dev = 0.99).

\begin{tabular}{|l|l|l|l|l|l|}
\hline Source & DF & SS & MS & F- value & p-valueProb $>$ F \\
Model & 4 & 48.34 & 12.09 & 12.31 & $0.0001^{*}$ s \\
Date Powder rate & 25 & 24.55 & 0.98 & 2.36 & 0.7445 \\
Residual & 20 & 22.20 & 1.11 & 0.2766 \\
Lack of Fit Pure Error & 5 & 2.35 & 0.47 & $0.1736^{* *} n s$ \\
Cor Total & 29 & 72.89 & & \\
\hline
\end{tabular}

Table 3: statical analysis

\begin{tabular}{|l|l|l|l|}
\hline Std. Dev. & 0.99 & R-Squared & 0.6632 \\
\hline Mean & 9.85 & Adj R-Squared & 0.6093 \\
\hline C.V. \% & 10.06 & Pred R-Squared & 0.4915 \\
\hline Press & 37.06 & Adeq Precision & 13.759 \\
\hline
\end{tabular}

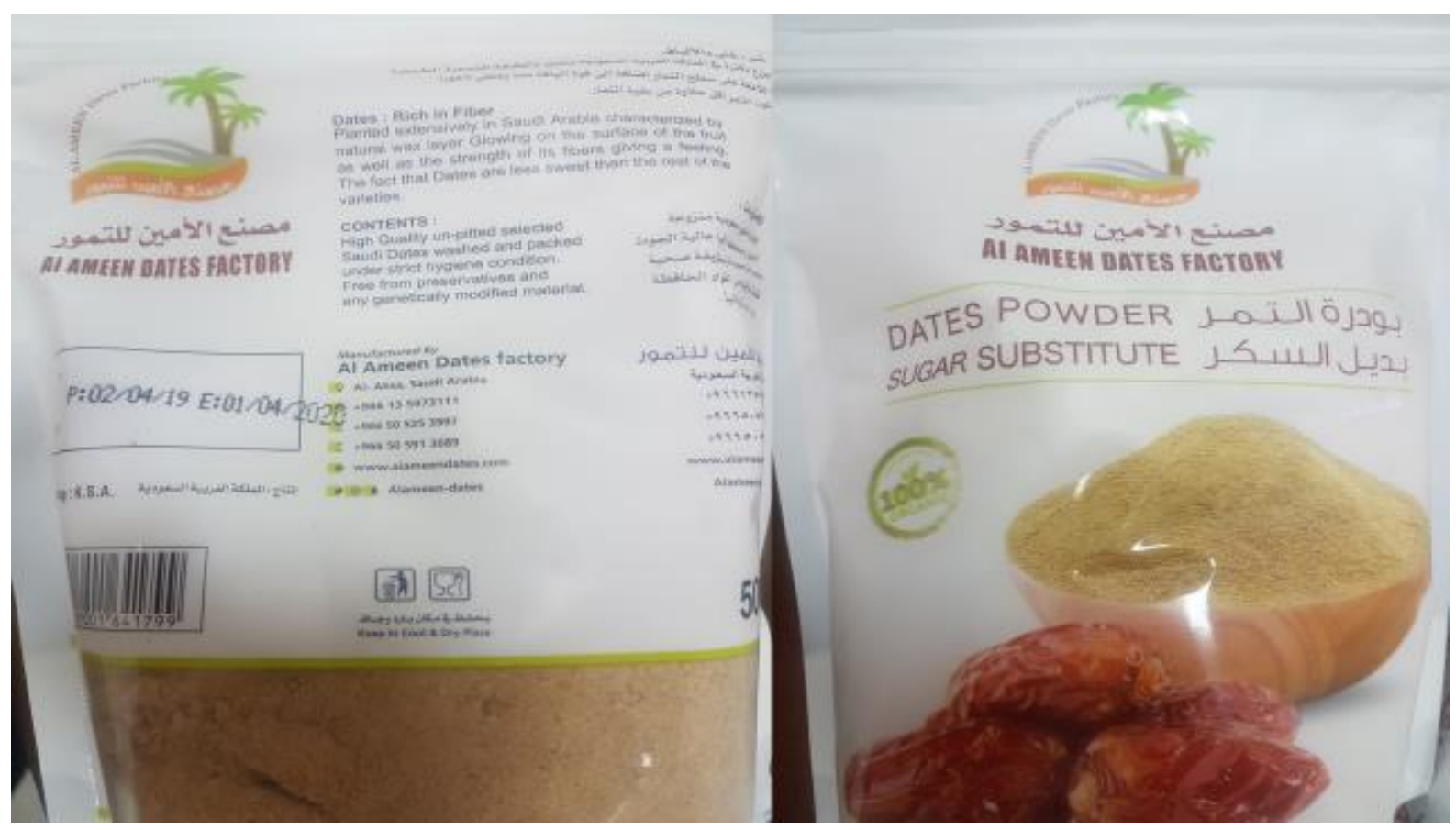

Figure 2: Date powder were bought from AL AMEEN DATES FACTORY (DATES POWDER- SUGAR SUBSTITUTE) Al HsSaKSA www.alameendates.com

\section{REFERENCES}

4 Al-Taweil HI, Noura KMS, Ekhlass MT, Use of date syrup as alternative carbon source for microbial cultivation. World Journal of Microbiology, 2015; 2(1):022-025. ISSN: 2141-5032

5 Ojokoh AO and Ekundayo FO. Evaluation of the performance ofsweet potato infusion as a medium for culturing yeasts. J. FoodTechnol. 2005; 3(3):440-443.

6 Al-Azzauy AA and Hassan AM. The beetroot juice as a bacterial growth and maintenance medium for many pathogenic bacteria. IraqiJournal of market research and consumer protection. 2011; 3(5):147-161.

7 Zahraa Abd Alrazaq Abd- alameer Alkhfaji. Bee collected pollen load (BCPL) as alternative culture media for bacterial and yeast growth/J. Pharm. Sci. \& Res. 2018; 10(4):830-835.
1 Famurewa 0 and David OM. Formulation and evaluation ofdehydrated microbiological media from avocado pea. Research Journal of Microbiology. 2008; 3(5):26-330. https://doi.org/10.3923/jm.2008.326.330

2 Annan-Prah, Akorli SY and Sedofia KB. Growth and culturalcharacteristics of selected bacteria on Cowpea Agar (Vignaunguiculata). African Journal of Microbiology Research. 2010; 4(23):2626-2628, Available online http://www.academicjournals.org/ajmr ISSN 1996-0808 (C)2010 Academic Journals

3 Arulanantham R; Pathmanathan S; Ravimannan N and NiranjanK. Alternative culture media for fungal growth using differentformulation of protein sources. Annals of Biological Reserch. 2014; 5(1):36-39. 
Association No. 151 Arabellastr. 481925 Munich (DE) Information valid as of: 05 December 2008 (05.12.2008).

11 Lonsane, B.K. \& Ramesh, M.V. Production of bacterial thermostable-amylase by solid state fermentation: a potential tool for achieving economy in enzyme production and starch hydrolysis. Advances in Appl. Microbiol. 1990; 35:1-/56. https://doi.org/10.1016/S0065-2164(08)70242-9

12 Difco Laboratories. Difco manual of dehydrated culture media and reagents for microbiological and clinical laboratory procedures. 9th edition, Detroit, Michigan, USA. 1969
8 Bhattacharya S, Vijayalakshmi N, Parija S C. Uncultivable bacteria: Implications and recent trends towards identification. Indian J Med Microbiol 2002; 20:174-7. https://doi.org/10.1016/S02550857(21)03184-4

9 Jadhav et.al.: Formulation of cost effective alternative bacterial culture media using fruit and vegetables wasteInt J Cur Res Rev., 2018; 10(2).

10 Giovanni M,. Culture media formulations for industrial application. International Patent Classification: C12N 1/00 (2006.01); C12N 1/20 (2006.01). Agent(s): Hoffmann Eitle; 